\title{
PENINGKATAN KETERAMPILAN KADER DALAM PENGUKURAN PANJANG BADAN BAYI SEBAGAI UPAYA DETEKSI DINI STUNTING DI WILAYAH KERJA PUSKESMAS SUMBERSARI
}

\author{
Dahlia Indah Amareta 1), Puspito Arum²), Faiqatul Hikmah³) \\ 1) 2) 3) Jurusan Kesehatan, Politeknik Negeri Jember
}

\begin{abstract}
ABSTRAK
Stunting atau pendek merupakan keadaan yang menggambarkan terhambatnya pertumbuhan. Keadaan ini berlangsung kronis karena disebabkan oleh malnutrisi jangka panjang. Stunting berkaitan dengan peningkatan risiko kesakitan dan kematian, serta gangguan perkembangan kemampuan motorik dan mental, oleh karena itu stunting pada bayi dan balita perlu menjadi perhatian khusus. Pemantauan pertumbuhan khususnya panjang badan dan atau tinggi badan seharusnya dilakukan sejak dini untuk menilai normal tidaknya pertumbuhan anak. Kecamatan Sumbersari memiliki prevalensi bayi dan balita stunting sebesar 18\%, yang terdiri dari kategori sangat pendek dan pendek. Kegiatan pengukuran panjang badan hampir tidak pernah dilakukan pada saat jadwal posyandu, dikarenakan keterbatasan alat. Alat ukur panjang badan yang tersedia terbuat dari kayu, dengan karakteristik berat dan sulit dibawa. Keadaan ini menyebabkan kegiatan pengukuran panjang badan bayi dan balita tidak dapat dilakukan pada saat jadwal posyandu. Persoalan mitra yang muncul dari analisis situasi adalah kurangnya keterampilan kader dalam hal pengukuran dan penggunaan alat ukur panjang badan bayi dan balita, upaya deteksi dini terhadap stunting tidak dapat terlaksana dengan baik karena kegiatan pengukuran panjang badan bayi dan balita tidak dapat terlaksana dan ketidaktersediaan alat ukur panjang badan pada setiap kegiatan posyandu.

Luaran dari kegiatan Pengabdian Kepada Masyarakat ini adalah alat ukur panjang badan bayi dan balita portable dan Buku petunjuk operasional. Kegiatan koordinasi dengan mitra meliputi pengumpulan data dan informasi dengan wawancara dan observasi. Kegiatan survey dan desain alat di bengkel menghasilkan output alat ukur panjang badan yang bayi sesuai dengan keinginan dan kebutuhan mitra. Kegiatan pengabdian ini telah menghasilkan alat ukur panjang badan bayi dan balita portable dan buku petunjuk operasional yang diberikan kepada 8 Posyandu di Desa Antirogo Kecamatan Sumbersari Kabupaten Jember. Alat ukur tersebut telah dipergunakan dalam pengukuran panjang badan bayi dan balita saat kegiatan Posyandu.
\end{abstract}

\section{Kata Kunci: Alat ukur panjang badan, kader posyandu, stunting}

\section{PENDAHULUAN}

Stunting atau pendek merupakan keadaan yang menggambarkan terhambatnya pertumbuhan. Keadaan ini berlangsung kronis karena disebabkan oleh malnutrisi jangka panjang. Stunting didasarkan pada indeks pengukuran panjang badan atau tinggi badan menurut umur $(\mathrm{PB} / \mathrm{U}$ atau $\mathrm{TB} / \mathrm{U}$ ) dengan batas Z-score kurang dari $-2 \mathrm{SD}$.

Prevalensi stunting di dunia berdasarkan data dari World Health
Statistic 2012 adalah sebesar 26,7\%. Stunting merupakan salah satu masalah gizi yang masih banyak ditemukan pada anak di Indonesia, khususnya pada bayi dan balita. Prevalensi pendek bayi dan balita di Indonesia berdasarkan Riskesdas 2013 menunjukkan angka $37,2 \%$, yang terdiri dari $18 \%$ sangat pendek dan 19,2\% pendek. Angka prevalensi pendek bayi dan balita di propinsi Jawa Timur adalah 31,11\%.

Stunting berkaitan dengan peningkatan risiko kesakitan dan 
kematian, serta gangguan perkembangan kemampuan motorik dan mental, oleh karena itu stunting pada bayi dan balita perlu menjadi perhatian khusus. Pemantauan pertumbuhan khususnya panjang badan dan atau tinggi badan seharusnya dilakukan sejak dini untuk menilai normal tidaknya pertumbuhan anak. Deteksi dini penyimpangan pertumbuhan diperlukan untuk pemberian terapi lebih awal, sehingga memberikan hasil yang lebih baik dan mencegah terjadinya risiko yang tidak diinginkan. Pengukuran panjang badan dan atau tinggi badan harus diukur atau dipantau secara berkala, dimulai saat bayi baru lahir, usia 1, 2, 4, 6, dan 9 bulan.

Kecamatan Sumbersari merupakan salah satu kecamatan di Kabupaten Jember yang masih memiliki bayi dan balita stunting. Prevalensi bayi dan balita stunting di Kecamatan Sumbersari sebesar $18 \%$, yang terdiri dari kategori sangat pendek dan pendek. Jumlah bayi dan balita stunting di Kecamatan Sumbersari paling banyak terdapat di wilayah Kelurahan Antirogo dan Tegalgede.

Kegiatan pengukuran pengukuran panjang badan bayi dan balita seharusnya dilakukan pada saat jadwal posyandu, beserta dengan kegiatan penimbangan berat badan. Kegiatan pengukuran panjang badan hampir tidak pernah dilakukan pada saat jadwal posyandu, dikarenakan keterbatasan alat. Jumlah alat ukur panjang badan bayi dan balita yang dimiliki puskesmas Sumbersari belum dapat memenuhi kebutuhan, sehingga alat ukur panjang badan yang ada hanya ditempatkan di puskesmas atau puskesmas pembantu. Alat ukur panjang badan yang tersedia terbuat dari kayu, dengan karakteristik berat dan sulit dibawa. Keadaan ini menyebabkan kegiatan pengukuran panjang badan bayi dan balita tidak dapat dilakukan pada saat jadwal posyandu. Hal ini menyebabkan pemantauan pertumbuhan dan deteksi dini terhadap stunting tidak dapat berjalan secara ideal. Ketidaktersediaan alat menyebabkan kurangnya keterampilan kader dalam mengukur panjang badan bayi.

Persoalan mitra yang muncul dari analisis situasi adalah kurangnya keterampilan kader dalam hal pengukuran dan penggunaan alat ukur panjang badan bayi dan balita, upaya deteksi dini terhadap stunting tidak dapat terlaksana dengan baik karena kegiatan pengukuran panjang badan bayi dan balita tidak dapat terlaksana dan ketidaktersediaan alat ukur panjang badan pada setiap kegiatan posyandu.

Tujuan dari kegiatan Pengabdian Kepada Masyarakat ini adalah memberikan solusi kepada kader posyandu di wilayah kerja Puskesmas Sumbersari dengan pembuatan alat ukur panjang badan bayi dan balita yang kemudian dihibahkan kepada mitra.

\section{TARGET DAN LUARAN}

Target dari kegiatan Pengabdian Kepada Masyarakat ini adalah (a) Meningkatkan keterampilan kader dalam hal pengukuran panjang badan bayi dan balita, (b) Meningkatkan upaya deteksi dini terhadap stunting, (c) mencegah terjadinya risiko kesehatan akibat keadaan stunting.

Luaran dari kegiatan Pengabdian Kepada Masyarakat ini adalah alat ukur panjang badan bayi dan balita portable dan Buku petunjuk operasional. Alat ukur panjang badan bayi dan balita dengan bentuk ringkas, ringan dan mudah dibawa. Alat ini dibuat dengan menggunakan bahan stainless steel. Ukuran alat disesuaikan dengan panjang bayi atau balita yang belum dapat berdiri $(100 \mathrm{~cm})$. Alat ini dirancang memiliki bentuk yang ringkas (mudah dilipat dan diringkas), ringan dan mudah dibawa serta dapat dimasukkan dalam tas jika sedang tidak digunakan, sehingga kader atau tenaga kesehatan dapat dengan mudah membawa ke lokasi posyandu. Buku petunjuk 
operasional digunakan sebagai panduan cara menggunakan alat ukur panjang badan bayi dan balita yang akan digunakan untuk mengukur panjang badan bayi dan balita.

\section{METODE PELAKSANAAN}

Kegiatan Pengabdian Kepada Masyarakat ini dalam memecahkan masalah yang muncul mencakup 5 tahapan kegiatan, yaitu studi pustaka, survei lapangan dengan metode wawancara dan observasi saat pelaksanaan posyandu. Kegiatan inti berupa desain dan perancangan alat, tahap penyerahan alat kepada mitra, memberikan pelatihan dan pengarahan di lapangan bagaimana cara pengukuran panjang badan bayi dan balita dengan menggunakan produk alat ukur panjang badan yang dihasilkan, serta tahap memantau perkembangan tentang penggunaan produk di lapangan.

\section{HASIL DAN PEMBAHASAN}

Kegiatan Pengabdian
“Peningkatan Keterampilan Kader
dalam Pengukuran Panjang Badan Bayi
sebagai Upaya Deteksi Dini Stunting (Di
Wilayah Kerja Puskesmas Sumbersari)"
telah selesai dilaksanakan sesuai
dengan tahapan proses yang dipaparkan
pada metode pelaksanaan.
Kegiatan koordinasi dengan
mitra meliputi pengumpulan data dan
informasi dengan observasi di wilayah
kerja Puskesmas Sumbersari serta
mengidentifikasi kebutuhan mitra
dengan mewawancarai tenaga
kesehatan yang bersangkutan. Hampir
tidak ada kendala yang dihadapi pada
tahap ini, karena mitra sangat koperatif
terkait dengan memberikan informasi
yang dibutuhkan.

Kegiatan survey dan desain alat di bengkel menghasilkan output alat ukur panjang badan yang bayi sesuai dengan keinginan dan kebutuhan mitra, serta diskusi tentang desain alat dengan pemilik bengkel. Kendala yang dihadapi pada tahap ini adalah kesulitan menterjemahkan ide alat ukur panjang badan bayi menjadi bentuk alat ukur panjang badan bayi yang diinginkan. Namun pemilik bengkel sangat kooperatif membantu dalam proses tersebut sehingga kegiatan revisi desain alat di bengkel dapat berjalan dengan baik. Kegiatan ini dilakukan karena berdasarkan desain awal alat ada beberapa hal yang perlu diperbaiki. Kendala yang dihadapi pada tahap ini adalah tim pengabdian dan pemilik bengkel kembali harus menyamakan persepsi terkait dengan bentuk alat yang diinginkan. Kegiatan ini dilakukan setelah alat ukur panjang badan bayi sudah selesai dikerjakan. Revisi bentuk alat ukur panjang badan dilakukan karena masih ada bagian yang kurang sesuai dengan prinsip dan cara kerja alat.

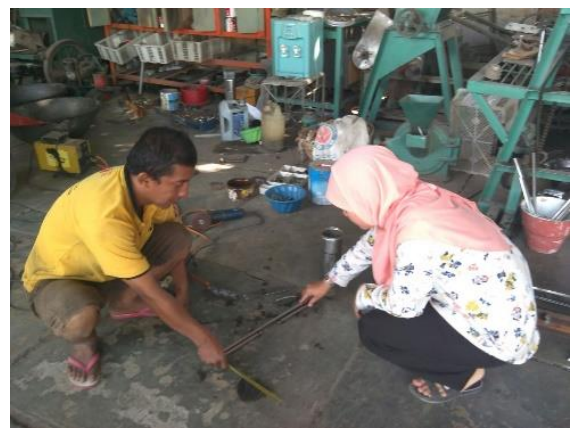

Gambar 1 Proses Perancangan Alat

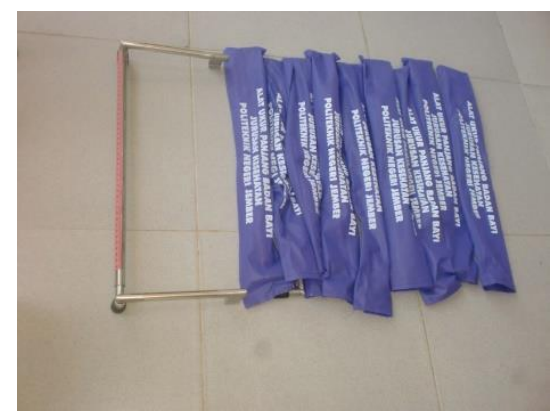

Gambar 2 Luaran berupa Alat Ukur Panjang Badan Bayi dan Balita

Koordinasi pelaksanaan kegiatan dengan mitra dilakukan untuk persiapan pelaksanaan kegiatan pengabdian kepada masyarakat, yang 
meliputi tempat, waktu, peserta kegiatan, dan persiapan lain. Kendala yang dihadapi adalah mitra belum bisa menjadwalkan kegiatan pengabdian kepada masyarakat pada awal bulan Agustus dikarenakan bertepatan dengan program kegiatan puskesmas dan posyandu, salah satunya adalah bulan pemberian vitamin $A$.

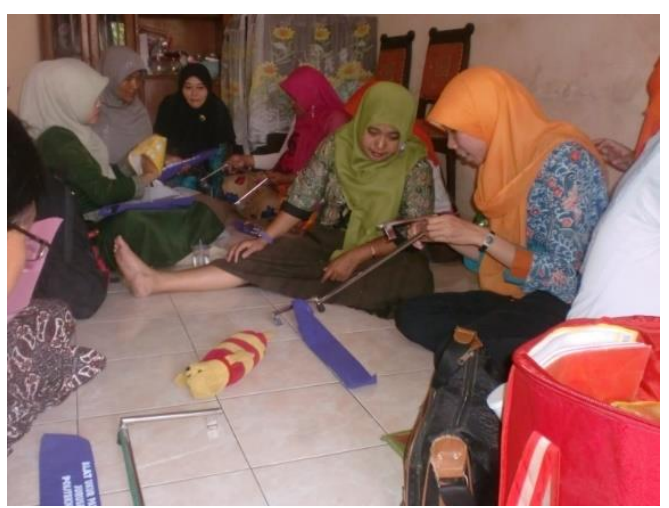

Gambar 3. Pengarahan Penggunaan Alat Ukur Panjang Badan pada Bidan dan Kader Posyandu

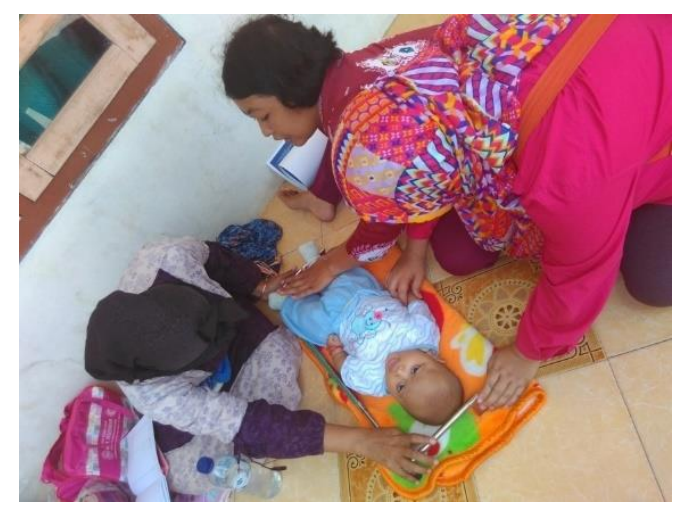

Gambar 4 Kegiatan monitoring ke Posyandu Catleya 65

Pelaksanaan kegiatan penyerahan alat ukur kepada kader yang seharusnya dilakukan pada tanggal 11 Agustus 2015 diundur menjadi tanggal 1 September 2015 di lokasi Posyandu Catelya 61 kegiatan disertai dengan pengarahan tentang cara penggunaan alat ukur panjang badan bayi. Kegiatan ini melibatkan bidan desa dan 2 orang mahasiswa. Masing-masing anggota tim memiliki job dekripsi dalam kegiatan ini. Kegiatan pengarahan dapat berjalan dengan baik, dibuktikan dengan antusiasme pada kader mempelajari tata cara penggunaan alat ukur panjang badan. Selama ini kader masih menggunakan metlin untuk mengukur panjang badan bayi. Hal tersebut tidak direkomendasikan karena metlin sukar diposisikan lurus dan sejajar dengan garis tubuh bayi. Masalah ini dapat diatasi dengan alat panjang badan yang kami rancang karena menggunakan staninless yang bentuknya kaku/rigid (tidak mudah berubah). Alat ini dibuat portable dengan tujuan memudahkan kader jika perlu melakukan pengukuran panjang badan saat kunjungan rumah. Pengukuran panjang badan di posyandu dilakukan setiap 3 bulan sekali. Namun karena keterbatasan alat dan sumber daya, pengukuran tinggi badan tidak selalu dapat dilakukan.

Evaluasi dan pemantauan terhadap penggunaan alat ukur panjang badan dilakukan dengan mengikuti jalannya posyandu pada beberapa lokasi yang telah memperoleh alat ukur panjang badan bayi yaitu Posyandu Catelya 62 dan Posyandu Catelya 65 pada bulan September. Kader mulai menggunakan alat ukur tersebut untuk mengukur panjang badan bayi. Kendala yang sering dihadapi adalah kesulitan memposisikan bayi yang sudah dapat duduk dan merangkak sendiri. Pengukuran panjang badan bayi seharusnya dilakukan dalam keadaan berbaring. Bayi usia 9 bulan ke atas bayi mulai sulit diposisikan berbaring, apalagi jika mereka tahu ada alat ukur di sampingnya. Solusi untuk menghadapi permasalahan tersebut adalah dengan menyediakan alas tipis untuk bayi terlentang tanpa paksaan sehingga memudahkan kader mengambil posisi yang tepat dari arah samping untuk melakukan pengukuran. Kendala lain yang dihadapi adalah ketelitian kader untuk memposisikan alat ukur pada posisi siku. Hal ini membutuhkan pelatihan dan pembiasaan penggunaan alat. Buku panduan penggunaan alat ukur panjang badan sangat membantu 
kader dalam mempelajari penggunaan alat ini

\section{KESIMPULAN DAN SARAN}

Kegiatan pengabdian ini telah menghasilkan alat ukur panjang badan bayi dan balita portable dan buku petunjuk operasional yang diberikan kepada 8 Posyandu di Desa Antirogo Kecamatan Sumbersari Kabupaten Jember. Alat ukur tersebut telah dipergunakan dalam pengukuran panjang badan bayi dan balita saat kegiatan Posyandu. Perlu dilakukan monitoring terhadap keberlanjutan kegiatan pengukuran panjang badan bayi dan balita untuk mendeteksi stunting dan diperlukan dilakukan kegiatan kalibrasi untuk alat ukur panjang badan yang dihasilkan agar hasil yang diperoleh akurat.

\section{DAFTAR PUSTAKA}

Badan Penelitian dan Pengembangan Kesehatan Kementerian Kesehatan RI. Riset Kesehatan Dasar 2013. Jakarta: Kementerian Kesehatan RI

Nutrition Lanscape Information System (NLIS) Country Profile Indicator 2010. Interpretation Guide. Geneva. World Health Organization
World Health Organization.World Health Statistics 2012. Available from

www.who.int/gho/publication/w oeld_health_statistics/EN_WHS20 12

Yunitasari L. 2.12. Perbedaan Intellegence Quotient (IQ) Antara Anak Stunting dan Tidak Stunting Umurr 7-12 tahun di Sekolah Dasar (Studi pada Siswa SD Negeri Buara $04 \quad$ Kecamatan Ketanggungan, Kabupaten Brebes). Jurnal Kesehatan Masyarakat.; Volume 1 Nomer 2 